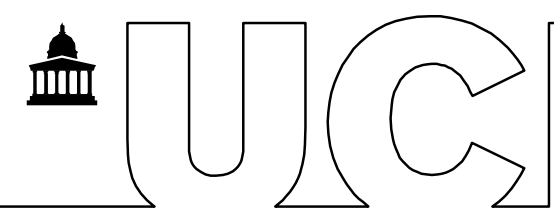

Phelps, NA; Wijaya, HB; (2016) Joint action in action? Local economic development forums and industry cluster development in Central Java, Indonesia. International Development Planning Review (In press). Downloaded from UCL Discovery: http://discovery.ucl.ac.uk/1473221.

\title{
ARTICLE
}

\section{Joint action in action? Local economic development forums and industry cluster development in Central Java, Indonesia}

\author{
Nicholas A. Phelps ${ }^{1}$ and Holi bina Wijaya ${ }^{2}$ \\ ${ }^{1}$ Bartlett School of Planning, University College London, 22 Gordon Street, London, WC1H \\ OQB; E-mail: N.phelps@ucl.ac.uk. \\ ${ }^{2}$ Holi bina Wijaya, Urban and Regional Planning Department, Diponegoro University, \\ Kampus UNDIP Tembalang, Semarang; E-mail: holibinawijaya@yahoo.com.
}

\begin{abstract}
It has been argued that the growth potential of industry clusters in developing countries is dependent on join action to release external economy effects that otherwise remain latent. In this paper we report on the progress and impacts of a programme in Central Java to develop capacity for joint action in industry clusters via economic forums in local government jurisdictions. We focus in on the emerging relationship between industry clusters and their respective economic forums in four local government jurisdictions. Despite progress, the findings reveal the difficulties of developing new institutions to support joint action. These difficulties follow from the limits presented by the private sector dynamics underlying industry clusters and from variations in local government organisation, resourcing and understandings of the remit of these new institutions.
\end{abstract}

\section{Introduction}

It has been argued that the many industry clusters in developing countries fail to develop 'collective efficiencies' since external economies (the measurable pecuniary and unmeasurable technological advantages arising from the spatial clustering of businesses (see, for example, Scitovsky, 1954)) can remain latent unless mobilised by joint action (defined as conscious cooperation among businesses (see Schmitz, 1999)) and that this, in turn, is a failure of public policy (Schmitz, 1995, 1999). ${ }^{1}$ The 'collective efficiencies' of developing country industry agglomerations - a term used in development studies - are seen as resulting from the effects of joint action upon erstwhile latent external economies: industrial clusters in Indonesia were an inspiration for this line of thought (Sandee et al 2002, 1994, Sandee and Weijland, 1989; Weijland, 1999). However, optimism surrounding the prospects of these clusters, based on their similarity to groups of flexibly specialised firms in 'the Third Italy', gave way to pessimism surrounding the effects of their integration into global value chains (Humphrey and Schmitz, 2002). Consequently, research into the potential for joint action to stimulate the development of such clusters has been limited.

This paper focuses on the potential for institutional support for joint action through an examination of a programme in the Indonesian province of Central Java to create new institutions to develop economic strategy-making capacity, including joint action for industry clusters. A Forum Pengembangan Ekonimi dan Sumber Daya (Economic and Resource

\footnotetext{
${ }^{1}$ Notwithstanding the limitations of the term cluster (Martin and Sunley, 2003), we use the terms agglomeration and cluster interchangeably given the prevalence of the term within the development studies literature and in the Central Java policy context.
} 
Development Forum, FPESD) was established at provincial level in central Java supported by German development organisation GIZ. Under the FPESD, forums for economic development and employment promotion (FEDEP) have been established at the local government (city and district) level to organise local industry into a series of Forums Rembuk Klaster (cluster discussion forums, FRK) (GTZ, 2004; P5 Universitas Diponegoro, 2014).

We begin by reviewing the literature regarding joint action and industry clusters, questioning the latency of such external economy effects and the possibilities for policy to stimulate joint action among businesses in industry clusters in developing countries. We then describe the origins and aims of a new set of institutions in Central Java to foster industry clusters and describe our research methods. In particular we draw on a comprehensive monitoring survey of all FEDEPs (P5 Universitas Diponegoro, 2013) as well as interviews focusing on the relationship between three batik and three wood/rattan working clusters and their respective FEDEP organisations in four local government jurisdictions. The conclusions highlight the importance of having realistic expectations regarding the possibilities for public policy to fashion joint action not least because of the effects of the segmentation of industry on the latency of external economy effects and the, as yet, limited capacity and adaptive efficiency of new institutions designed to support joint action in industry clusters.

\section{The limits of joint action in industry clusters}

Craft industry clusters in developing countries appear similar to the 'social network' model (Gordon and McCann, 2000) of agglomeration found in the industrial districts of 'the Third Italy'. However the former have been markedly less successful than the latter, leading analysts to highlight the impediments to joint action and the mobilisation of external economies or collective efficiencies among businesses in developing countries (Weijland, 1999). ${ }^{2}$ That is, latent external economies of specialization in craft industry clusters in developing countries are in need of release through the joint action resulting from self-organisation among businesses or via government policy (Schmitz, 1999). Drawing on the case of Indonesia, we identify some of the limits to this story in terms of: assumptions regarding the latency of external economy effects and the design of appropriate and adaptively efficient institutions capable of stimulating joint action.

The latency of external economies

The latency of external economies in developing country industry clusters cannot be assumed in a situation where many are composed of enterprises whose mode of operation is survival (Altenburg and Meyer-Stamer, 1999; Nichter and Goldmark, 2009). Where external economies are latent, their relationship with joint action remains unclear.

A question remains whether industry clusters in developing countries have the critical mass to sustain the formation of external economy effects. In Indonesia, the Asian financial crisis coupled with the initial effects of decentralisation legislation has meant that many industry clusters have experienced severe retrenchment.

While the most successful export-oriented clusters in developed countries may exhibit vertical as well as horizontal disintegration (Scott, 1983, 1986) (involving returns to scale and product differentiation), the more common tendency has been for industry clusters in developing countries to be characterised only by horizontal disintegration with little product differentiation - this is often the case in Indonesia including, to an extent, the cases we examine here (JICA,

${ }^{2}$ A further complication is that there are distinctly different forms of industry agglomeration. Gordon and McCann (2000) contrast 'pure Marshallian' and 'social network' forms (in which external economies are likely to be latent and available to small businesses) with the 'production complex' (where vertical integration around a few large firms precludes the development of external economies). 
2004). The balance between processes of internalisation and externalisation in (and between internal and external constraints on) business development are vital to the design of appropriate institutions in support of joint action in developing countries. The neglect of this issue in discussions of the potential contributions of public policy to collective dynamics is all the more surprising given the literature pointing to the constraints on individual firms in developing countries (Schmitz, 1982) including Indonesia (Turner, 2003). Vertical disintegration rarely seems to extend into many non-production activities locally within developing countries, underlining how the possibilities for industry clusters need to be understood in a context in which the sales, marketing and distribution of these products continues to be dominated by western 'buyers' (Humphrey and Schmitz, 2002; Perlin, 1983). Consequently, it is far from clear whether informal industry clusters can draw upon or capture the external economy effects commonly associated with industrial agglomeration (MorenoMonroy, 2012).

The relationship between internal and external economies is connected to the origin of joint action and policy design. Joint action can occur spontaneously among businesses as a consequence of, or alongside, government intervention (Schmitz, 2005). However, where significant external economies are latent, they may not be amenable to public policy. Hierarchical privately-organised joint action may be quite resistant to public policy compared to horizontal joint action among businesses as processes of vertical disintegration may be subject to limits quite early on in a segmented local economy (Taylor and Thrift, 1982) with larger firms organising industries along ethnic and extended family lines. Indeed, for informal enterprises to capture important external economy effects, 'the relationships between formal and informal enterprises along the value chain must be symmetrical and non-hierarchical' (Moreno-Monroy, 2012: 2024). This has led Moreno-Monroy (2012) and Nichter and Goldmark (2009) to suggest that policy needs to recognise business segmentation.

In sum, it may simply be that industry clusters represent no particular advantages to the businesses involved (Perry, 2005). Moreover, where external economies are latent, their mobilisation through joint action involves questions of institutional design - the issue to which we now turn.

Institutions for joint action

There seems little doubt that institutions have been co-present in industry clusters (Amin and Thrift, 1992; Storper, 1995) but this says nothing about their causal role in the release of external economies. The theory of agglomeration based on the concept of external economies continues to contain troublesome elements of circularity regarding cause and effect (Phelps, 1992). While empirical studies show joint action to be apparent (Scott, 2002) and to have contributed unevenly to improved business performance (Nadvi, 1999, 2007) in developing country industry clusters, it is unclear whether such joint action is cause or effect of external economies. Jacobs (1969) argued that Marshallian agglomerations embodied sterile divisions of labour compared to the diversity that sustained the growth a development of the very largest cities. The implication is that strongly institutionalised manifestations of joint action - such as business representative organisations involved with branding, training and skills development - may be a consequence of past growth and competitive success.

Furthermore, there is a case for suggesting that the limitations on public policy in support of joint action at the local level in developing countries have been underestimated. First, although policy prescription has shifted from an emphasis on 'getting prices right' to 'getting institutions right' (Rodrik, 2008) as a reaction to insights from evolutionary and institutional economics (North, 1990), there remains a need for sensitivity to historical context surrounding the design of appropriate of institutions for joint action. The term 'embedded liberalism' attached to many western economies reminds us that key institutions - including those designed to foster joint action - have emerged within societal contexts which nurtured the formation and functioning of markets. The present-day institutional bases to the social network model of industry 
agglomeration in the likes of 'the Third Italy' have taken hundreds of years to evolve. However, it is unclear quite how new or reformed institutions capable of performing a parallel role in developing countries can emerge in the short term. The fact that 'best practice' continues to be promulgated by international organisations and non-governmental organisations (NGOs) is likely to be part of the problem. Best practices are, by definition, de-contextualised, partial in their embrace of points of policy and regulatory leverage, and are likely to be inappropriate to the needs of developing countries (Rodrik, 2008). The financial and human resources within, and technical capacity available to, the local government sector in developing countries are often limited and - crucially - unstable, such that the value of imported policy solutions based on incremental improvements in stable fiscal and political systems is questionable (Masser, 1986). Indeed the private sector may exist and develop in spite of government and the oft-cited 'costs of doing business'. Worse, the mimicking of such best practice is one technique by which failures in policy implementation are obscured as local and national governments seek to 'look like a state' (Pritchett, Woolcock and Andrews, 2013: 4).

Second, the question of appropriate design of institutions reveals itself not as a case of rational selection from a number of ahistorical templates but as choices taken within socially and culturally embedded perceptions of extant economic and institutional realities and the possibilities for change (North, 2010). Policy interventions rarely start from where they assume, while what North (2010) terms the 'adaptive efficiency' of institutions may be lacking in developing countries. In Central Java in Indonesia, the creation of new institutions in support of joint action in industry agglomerations has been overlain on other elements that embody a measure of, or basis for, localised joint action. ${ }^{3}$ It is also important to recognise that policy to help fashion new institutions in support of joint action also took place against a backcloth of governmental decentralisation which has produced a decentralisation of rent seeking behaviour in political and bureaucratic circles (Hadiz and Robison, 2005) such that interim institutions - such as the FEDEPs considered here - emerging between state and society may be open to capture by local elites (Wollenberg et al, 2006). The calibre and credibility of local political leadership appears to be the determining factor in the progress of local governments towards greater regulatory efficiency and institutional reform (Von Luebke, 2009), yet it is rarely in evidence or consistent over time. The problems extend from political leadership into aspects of the organisation and efficacy of local administrations with implications for local policy initiation and implementation.

\section{Research contexts and methods}

Central Java, (figure 1), provides a unique region to study industry clusters and the support for them. A system of FEDEPs or local economic forums in central Java was proposed by GIZ in 2001, couched in terms of creating new local institutions for promoting economic development under its Economic and Human Resources Development (EHRD) programme. Here GIZ's interests were positioned rather differently from the calls for macro-economic and regulatory reform found in much academic and policy advocacy, as the minutes of the meeting at which agreement on the EHRD programme reveal:

\footnotetext{
${ }^{3}$ There are at least three elements here. First, musyawarah (discussion or negotiation) and arisan (a rotating local savings association) in which contributions from members are distributed at regular meetings are a legacy of traditional Javanese culture. Second, the rituals of Islamic religion provide a platform around which social gatherings take place and include the traditions of pengajian (regular meetings centred on prayers and readings) and zakat (alms-giving) which involves the redistribution of a proportion of an individual's wealth at the time of the Eid al Fitre celebrations marking the end of Ramadhan. Third, as well as national industry associations (and their local branches) which remain reasonably vibrant, there are also the remnants of once powerful and well-organised cooperatives for small businesses from the time of 'guided democracy' under Sukarno's presidency (1945-1967).
} 
'One of the factors to determine the existence of industrial competitiveness is incentive, which covers macroeconomic management, trade policy, and institutional rules and regulations. However, two other determinants, which are not less important, are market $\ldots$ and related institutional development (training institutions, technology support institutions, and financial institutions)' (GTZ 2001).

As the same minutes went on to describe:

'The overall goal of the programme is to promote Indonesia's economic and human resources development in industrial sector by means of improving the effectiveness of public policies through the enhancement of close collaboration between governmental and private stakeholders at all levels in an effort to reach a social consensus which shall be useful for the creation of consistent policies and their implementation' (GTZ, 2001).

The EHRD programme was applied in Central Java, under the auspices of The FPESD. After the creation of six trial local economic development and employment promotion forums (FEDEPs) in Klaten, Cilacap, Wonosobo, Jepara, Pati and Pekalongan in 2000, the provincial level FPESD was established in August 2001 (P5 Universitas Diponegoro, 2014).

The FEDEPs were not intended as executing bodies for programmes/projects but were intended as multi-stakeholder dialogue fora intended to: facilitate, mediate and coordinate the domestic development process; develop the vision for domestic development; generate development strategies; define, monitor, evaluate application of development programmes/projects; voice sectoral demand; provide input for policy makers; enable cooperation among stakeholders, and; coordinate sectoral policies (GTZ, 2004: 7-8). Among the benefits anticipated were capacity building among stakeholders, the mobilisation of domestic resources and a sustained focus on economic development (GTZ, 2004: 10). The intention was for the FEDEPs to be assisted and funded by, but to exist outside of, local government and draw upon advice and input from the private sector which organises industry cluster forums. The provincial government contributes funds towards the establishment and maintenance of local FEDEPs, though these are to cover only the costs of arranging and attending meetings and the training of FEDEP and industry representatives. As new institutions encouraged at the local level within Central Java, there is no singular template for the organisation, strategic priorities, timetable of meetings and specific interventions of the FEDEPs, though most of the FEDEPs have a focus that maps onto or uses the language associated with industry clusters.

These aspirations for the creation of institutions to support joint action within industry clusters were catapulted into a turbulent period in Indonesian history. Legislation ushered in a period of pemekaran (the creation of many new local governments), the creation and subsequent revoking of new local laws and taxes, and ambiguities over the responsibilities of central, provincial and local governments, with impacts on businesses. The GIZ EHRD programme recognised, though underestimated, the impact of such turbulence when spelling-out the objective to 'restructure and revitalize business institutions' many of which had collapsed.

GIZ funded the development of an initial 6 local government FEDEPs jointly with provincial government, with the latter promoting and part-funding the remaining 29 of 35 FEDEPs across Central Java thereafter (see figure 1). Provincial government allocates money for the continuing development of the local FEDEPs, with the idea being that this money should be matched with funds from local government budgets. Local governments have augmented this funding by typically $30-40 \%$ of the value of provincial government funds. Over time, the coverage of these new FEDEP institutions in Central Java has increased from the initial 6 in 2001, to 24 in 2006, to complete coverage of 35 in 2011 with FEDEP Boyolali now inactive leaving 34 in 2013 (P5 Universitas Diponegoro, 2014). 
In what follows, we draw on data collected for a province-wide monitoring and basic evaluation of the FEDEP programme completed in 2013. Data on the performance of each of the 35 FEDEP organisations created across central Java was collected with a score given for each of 9 metrics in 2011. Data were collected again in 2012 but with a revised set of scores attached to each of the 9 criteria. These data were collected in a series of meetings with a need to demonstrate documentary evidence relating to each of the 9 criteria. These quantitative data set the context for understanding new institutional development in support of joint action in industry clusters and provide a basic means of gauging the adaptive efficiency of such new institutions.

These data are supplemented by interviews with stakeholders in six industry clusters (batik and wood/rattan industries) within four local government jurisdictions. The batik production process involves a limited vertical division of labour - such as pre-shrinking and drying of cotton materials, copper stamp making, the drawing and stamping of wax outlines and designs, dying and manufacture of garments. The two largest companies (which are not part of this study) have also engaged in backward vertical integration into the production of cotton textiles. Businesses have also sought forward vertical integration into the retail, restaurant and accommodation business involving geographically extensive patterns of putting-out of different activities to different businesses and homeworkers well beyond the clusters within the surrounding districts. In the case of the wooden and rattan furniture and wood carving clusters, the typical pattern is one of a horizontal division of labour with different producers specialising in different designs before passing semi-finished items for finishing often by larger companies involved in distribution and export. As a result production is largely contained within particular villages within Jepara and Sukoharjo.

Coincidentally these clusters exist in some of the better performing local governments. However, as table 1 reveals, the characteristics of these four districts varies, setting the context for understanding the dynamics of the industry clusters and the efficacy of policy in support of joint action. As is to be expected, the two relatively compact cities of Surakarta and Pekalongan have more productive economies (higher GDP per capita) and lower rates of poverty than the larger rural or semi-rural districts of Sukoharjo and Jepara. Nevertheless, the latter jurisdictions are geographically extensive, contain significant populations and have experienced significant growth of non-farm enterprises.

We studied the batik industry in Surakarta - a city which has emerged as a model of local government (Bunnell et al, 2013; Phelps et al., 2014). We examined one wooden and one rattan furniture cluster in Sukoharjo - a district which together with Surakarta forms part of an urban corridor in which inter-locality competition and comparison has driven better local government performance (Von Luebke et al, 2009). The Pekalongan batik industry has been more commercially oriented than that in Surakarta. The wood carving cluster in Senenan village in Jepara was a more manageable one to study than the much larger wooden furniture cluster spread across the whole district. A total of 11 interviews were conducted with the FEDEP representatives and industry cluster representatives in March and July 2013. The interviews typically lasted 90 minutes and covered issues of the formation, organisation and strategic priorities of the FEDEP organisations, their impacts in terms of promoting joint action in, and the self-organisation of, the industry clusters.

\section{Joint action in action? Illustrations from Central Java}

In this section we examine the role of the FEDEPs in facilitating joint action across six industry clusters, drawing on interviews with FEDEP staff and industry cluster leaders in four local government areas and a criteria-based evaluation of the FEDEPs, with key findings summarised in table 3. 
The latency of external economies?

The activity of FEDEPs maps closely onto 175 agriculture, manufacturing and tourism industry clusters that are supported by public policy at local and provincial level. However, do all of these clusters have the critical mass to generate external economies? Some are composed of a handful of businesses scattered across a whole city and could hardly be said to be industry clusters or agglomerations. Others consist of sizable numbers of businesses in a single village. The diversity included under this label is indicative of a chaotic concept (Martin and Sunley, 2003).

In table 3 we indicate that several of our case study 'clusters' lacked critical mass. The sizeable wooden furniture industry in Jepara is composed of an estimated 16,000 businesses. The smaller specialised wood carving cluster of the village of Senenan within Jepara is made up of 32 business groups with the chairman of this industry preferring the label 'centre' rather than cluster due to its limited scale (Interview 2: Chairman, Senenan Wood Carving Cluster, 14 March 2013). The batik and rattan furniture industry clusters covered in this paper have recently collapsed to a point where it is debateable whether an industry cluster can be said to truly exist. The rattan furniture industry in Sukoharjo, for instance, collapsed from 510 businesses existing prior to 2007 to 193 by 2013 (Interview 3: Chairman, Rattan Cluster, 12 March 2013). There are presently an estimated 90 businesses in the Laweyan area, only 25 of which are production-oriented (Interview 4: Chairman, Batik Laweyan Cluster, 11 March 2013). With 120 or so businesses, Kauman is a larger but even less production-oriented cluster than Laweyan, with only an estimated 8 producers and 20 shops ordering from producers spread across the city region (Interview 5: Chairman, Batik Kauman Cluster, 10 March 2013).

As table 3 also summarises, the extent of vertical disintegration of production among the industry cluster examples that we examined is quite limited. In the batik industry in Surakarta, the tendency today is for a much reduced number of small and medium sized - essentially design and retail - companies to put out certain parts or all of the production process to individual home workers located outside the city (Interview 4). The batik cluster in Laweyan has been partially rejuvinated around activities such as homesteads and tourism and improvements in street furniture and marketing. On the one hand, this represents a vertical extension of the division of labour associated with batik into non-production activities which can add value. On the other hand, this does not represent a deepening of the division of labour within production activities themselves which might drive internationally competitive exports.

Both the batik industries of Laweyan and Kauman in Surakarta and the rattan furniture industry in the neighbouring district of Sukoharjo emerged as a consequence of the Mataram kingdom in Surakarta (dating to the 1700s). Historically, some batik was not a commodity as specific designs could only be worn by royalty, though it is best not to make over much of such constraints on industry development (Sekimoto, 2000). In Pekalongan the batik industry grew independently of royal behest and continues to be produced on a much greater scale by around 600 SMEs and thousands of homeworkers (Interview 6: Chairman, Secretary and exChairman FEDEP Pekalongan, 10 July 2013). Nevertheless, despite its scale, collective efficiencies appear to be a passive reflection of a large number of producers. There is horizontal disintegration of production and a large market for skill in the city but little in the way of explicit cooperation among batik producers (Interview 6).

It is unclear whether we can speak of the latency of external economies when many of the industry clusters that exist across the province have been initiated at the behest of government. This is the complaint of an interviewee from GIZ (Interview 1: Local Economic Senior Advisor, GIZ, 13 March 2013) and several of the industry cluster representatives interviewed confirmed that their industry cluster forums were formed at the behest of the FEDEP or the provincial government. 
There was also a degree of in-fighting among companies regarding the new institutions designed to promote joint action. This stems from the extant private sector organisation of industry clusters and exists despite the modest amounts of funding channelled via the FEDEPs. The rattan industry cluster in Sukoharjo would be a case in point. A cluster representative body was recently re-established but prior to a major crisis affecting the cluster in 2007 the collective organisation by companies themselves had collapsed several times. One of the reasons cited was that members of the board of the collective had used it for their own ends (Interview 3). This, in turn, was due to the structure of the industry locally with a gap in terms the financial resources and attitudes of 20 or so large companies and the many smaller companies to which they put out work. In the recent past, arrangements for smaller companies to make a loan payment to bigger companies in return for bulk purchases of material collapsed due to problems of slow repayment.

Thus, in table 3 we indicate that horizontal self-organisation was the norm across our study areas and industries. This was the case in the Senenan wood carving industry and the wooden furniture industry in Sukoharjo which are composed of small companies. In Senenan, the 32 businesses in one village have organised themselves into a cooperative taking in membership fees which have funded loans to individual businesses and the purchase and rent of equipment such as a compressor and table saw and for shared use by craftsmen (Interview 2). The wooden furniture industry in Sukoharjo is organised to make semi-finished products and for these to be finished and exported from Surakarta and Yogyakarta by exporters and buyers. While there are some opportunities for the development of the value chain locally, joint action has focused on more modest targets. Thus a collective of wooden furniture makers established itself in 2009 at the request of the local FEDEP and provincial government (Interview 7: Chairman, Wooden Furniture Cluster, 12 March 2013), taking financial collections that are redistributed on a syndicate basis with one business being selected each month to receive business development investment contributions. The collective has also taken a number of other initiatives. Since, it already has a brand with local exporters and buyers, they come to the collective which takes on the responsibility for distributing orders among members. It has also accumulated some of the contributions in order to purchase supplies of raw materials and distribute these to members.

The wooden furniture industry in Sukoharjo is one of the stronger examples of self-organised joint action by an industry cluster and has benefited from other investments, including Bank Indonesia's donation of an oven for wood hardening and a jointing machine from the Ministry for Cooperatives in Jakarta. Yet questions remain over the future of the industry cluster. Despite funding from the FEDEP and local government, there were complaints that support from the mayor was limited (Interview 7). Interest in joining from non-members is strong, though the present organisation of the collective (35 members out of an estimated 250-300 wooden furniture makers in Sukoharjo) cannot be expanded until the syndicated distribution of funds has completed a single cycle (Interview 7).

Surakarta's batik industry declined sharply during the 1980s and 1990s when many businesses closed or relocated from Laweyan and Kauman. Subsequently, the batik cluster in Laweyan was galvanised formally in 2004 prior to Surakarta emerging as a model of political and policy leadership nationally. The move was instigated by the private sector itself with a presentation to Bappeda (the economic planning department of the local government) and the then mayor. The main joint action so far has preceded the activities of the FEDEP and involved the construction of a waste water treatment facility funded by GIZ. Only 4 of the 25 batik producers do not contribute to its upkeep, though this does expose issues of 'free rider' behaviour. Aid from SIDA (Swedish International Development Cooperation Agency) has helped local companies reach the Swedish market through the communication of appropriate designs. It is estimated that the batik cluster in Laweyan has received in the order of 40 million rupiah (approximately US\$2940 at October 2015 exchange rates) under three projects. The FEDEP has channelled 6.5 million rupiah towards (US\$470) printing marketing brochures, 
while money for facilitating cluster meetings has also amounted to a further 10 million rupiah (US\$734) (Interview 4).

Appropriate and adaptively efficient institutions?

An immediate problem with the creation of a new institution such as the FEDEP at the local level is that of defining its purpose and its organisational design and in table 3 we indicate that this is one of the weaknesses of the FEDEPs. In the developing country context, the extended period of time over which the process of defining a role for a new institution like the FEDEP (and negotiating an understanding of that role among stakeholders) can take place should not be underestimated. The fact that confusion continued to be apparent at a recent annual progress review meeting of all FEDEPs in central Java in March 2013, fully a decade after the FEDEP policy was initiated, is evidence of this.

The FEDEP in Jepara was among the first six to be established in 2000 but interviewees suggested that it took three years to reach some understanding among stakeholders as to the role of the FEDEP. During this time there was great uncertainty about whether the FEDEP should be a think-tank or an executing organisation with the FEDEP attempting to provide technical assistance to businesses (Interview 8: Head of Economic Division, Bappeda and Secretary FEDEP Jepara, 14 March 2013). Moreover, some debate still remains regarding the purpose of the FEDEP, with its head wanting it to have a more powerful role akin to an economic commission. In Surakarta, suggestions for the creation of a business plan and value chain analysis to inform the work of the FEDEP with regard to batik Kauman have been regarded as too complicated for the current capacity of industry and the FEDEP.

The FEDEPs studied presented a range of roles in their development of joint action. In Jepara and Sukoharjo the FEDEPs were attempting to facilitate joint action across a large number of industry clusters. In Jepara, nine clusters were being supported, though active facilitation at least seemed to focus on a single cluster at any one time. In Sukoharjo, where progress in the formation of the FEDEP itself had been hampered by in-fighting among a range of industry interests, no such prioritisation is apparent. Here the FEDEP leader was appointed partly as an impartial figure and partly with a view to balancing these different industry interests. So protracted seem to have been the difficulties that a first round of meetings was only initiated in 2013 - over a decade after the FEDEP programme was inaugurated. This would appear to be one case of joint inaction as a result of conflicts over the very existence of the FEDEP and the perceived spoils to be distributed through it. In this case the FEDEP is attempting to facilitate the development of as many as ten clusters. This has meant that the FEDEP budget has been enough only to fund a series of meetings for each of the clusters in order for them to formulate policies for joint action with the FEDEP playing no direct role in the financing of projects other than for some limited training of each industry cluster representative.

It should be remembered that Sukoharjo is a district with a sizable population and economy. In the case of the batik industry much of the production activities that were formerly in Surakarta have moved to neighbouring jurisdictions such as Sukoharjo. Indeed, one cluster supported in Sukoharjo is a batik cluster which, according to figures quoted at interviews, is larger than those in Surakarta. This is an important feature of what McGee (1991) termed a desakota pattern of urbanisation - a little recognised but distinct challenge to the promotion of industry clusters, the organisation of joint action and the mobilisation of any external economy effects within a country like Indonesia. ${ }^{4}$ When initially interviewed there was no cooperation between the FEDEPs of the two jurisdictions despite such obvious economic connections,

${ }^{4}$ This desakota pattern tends to involve an organisation of production that is intermediate in multiple respects. Namely, between: urban and rural; agrarian and industrial; local agglomeration and spatial dispersal; formality and informality; aggressive accumulation and survival. 
though informal coordination among the FEDEPs of the Solo Raya (greater Surakarta) region has emerged since.

The Sukoharjo case contrasts with that in the neighbouring city of Surakarta where the focus has been on prioritising support for industry clusters one at a time and in providing direct support for some specific joint actions. The focus in Surakarta has been limited to the two batik industry clusters in Laweyan and Kauman. In fact, little direct support appears to have been offered to Laweyan where industry organised itself to provide something of an inspiration to the FEDEP's work in Kauman. Alongside the funding of meetings of the industry cluster, part of the budget of the FEDEP has been channelled into specific joint actions such as the creation of a cooperative shop in Kauman and road and street furniture improvements.

The design of these new institutions in support of joint action for industry clusters is exposed to issues of funding and human resources. Table 2 provides figures on the annual budgets for our four case study FEDEPs. It shows the provincial and the local contribution for each year and the sum of these contributions over five years. Overall, the total financial resource to the FEDEPs across the time period was modest and fairly similar - the FEDEP budget in Jepara being less than ten per cent more than Surakarta's. Nevertheless, table 2 also reveals variations in the total funding of FEDEPs in any given year underlining, in particular, the sorts of budgetary constraints that may impede policy transfer from developed to developing countries (Masser, 1986). Across the time period and across the four FEDEPs, the biggest variation was between the funding for Surakarta in 2011 and that for Jepara in 2009. Jepara experienced the biggest variations in total FEDEP budgets (varying from a high point in years 2009 and 2010 to a low in 2011) which coincided with the biggest variations in local contributions. Over the five year time period, the district allocation in Pekalongan was 59 percent more than in Jepara.

Some of the budget variation from year to year derives from the provincial government budget allocation itself as this is calculated on the basis of the performance of local governments and partly it seems because local FEDEPs have been asked to take on additional roles of coordinating sub-provincial meetings (Interview 8). However, the desire or ability of local governments to augment this allocation with their own funds varies over time and from place to place. For one of our interviewees the local allocation was dependent upon the inclination of the mayor (Interview 4) and in the experience of another it could fall to zero in a year that coincided with a local election (Interview 8).

In Indonesia these issues have been exacerbated by discontinuities in the effectiveness of local governments since the decentralisation legislation from 1999 onwards. This includes the effectiveness of leadership and vision projected by elected politicians. In the cases studied here, mayoral support for industry clusters was rarely in evidence. The mayor appears to have been involved in the business of the FEDEP in Pekalongan as a result of his attendance at a regular cycle of meetings (Interview 6). However, elsewhere, interviewees representing industry clusters were critical of a lack of support from their respective mayors (Interviews 4 and 7).

Then again, both local governments and industry clusters have been able to augment these resources with other sources of finance and technical assistance. GIZ has long been active in funding capacity building projects in Central Java including the provision of specialist design expertise after a study of the value chain of the rattan furniture industry in Sukoharjo (GTZ, 2008). Similarly, the leader of batik Laweyan commented that the major assistance received in Laweyan had not come via the FEDEP but other bodies such as GIZ (Interview 4).

It was the opinion of the GIZ consultant involved with the FEDEP programme that money was not the critical factor but the relevance of the policies formulated by each FEDEP and the technical capacity that could be mobilised (Interview 1). In most of our study locations then 
table 3 indicates that resources did not emerge as the critical issue regarding the adaptive efficiency of these new institutions given a generally strong commitment to and organisation the FEDEPs. The FEDEPs we studied did vary in their relationship to local government organisational structures and the staff time that could be called on. At one extreme the FEDEP in Sukoharjo appeared to be highly reliant on one individual who was the secretary for the FEDEP, organiser and attendee at all forty meetings across ten industry clusters scheduled for early 2013. At the other extreme, we were met by four people from the economic section of Bappeda who could represent the FEDEP in Jepara in some capacity.

The human resources that each FEDEP can call upon are also related to the composition of the FEDEP itself. The FEDEPs sit within local government bureaucracies and are often staffed by officers from relevant implementing government departments. For some this has proven precisely the problem for implementation. The complaint from the Chairman of the Laweyan batik cluster here was that the members involved with the FEDEP are local government 'conscripts' who lacked passion and the appropriate talent to implement projects (Interview 4). In other FEDEPs, such as Jepara, where the private sector membership exceeds the public sector (Interview 8), the issue may be less severe.

In several instances the FEDEPs have chosen not to support particular industry clusters perceiving them to be large enough to self-organise. In Jepara, the wooden furniture industry was not one of the nine supported by the FEDEP (Interview 8). With an estimated 16,000 businesses, the industry cluster is significantly export-oriented and organised through a branch of the national industry association ASMINDO. Joint action exists in a hierarchical sense both in terms of this peak industry association and the private organisation of the putting-out of production (Interview 2).

Something of the adaptive efficiency of these new institutions might be gauged through evaluations of the performance of the FEDEPs over four phases and a total of 23 detailed indicators (P5 Universitas Diponegoro, 2013). The four phases are: (1) the strengthening the institutional platform of the forum; (2) the mapping and analysis of district conditions; (3) the creation of an action plan; (4) the creation of an implementation programme. For each indicator a score (of $0,1,2,3$ etc.) is achievable with a total maximum score of 60 achievable. This scoring system was weighted towards the earlier phases with a maximum score of 26 available for phase 1, 11 for phase 2, 15 for phase 3 and 8 for phase 4 . The evaluation scores are presented in figure 2 from which several observations can be made.

First, only Boyolali does not have a FEDEP - a situation ascribed to the disinterest of the mayor who was unwilling to allocate funds from the local government budget. Second, almost all of the districts in Central Java had moved to the final phase of implementing their action plans by 2012. On the one hand, this is a positive story of the development of new institutions within a little over a decade. On the other hand, the greatest variation in performances across local governments was apparent with respect to the final two phases relating to the creation of action and implementation plans. ${ }^{5}$ Among a number of concerns raised by GIZ - the cosponsor of the FEDEP system - was the need for local capacity to support better policy design and implementation (Interview 1). Third, those local governments with some of the largest and most developed industry clusters - including the four local governments we examined generally had the better performing FEDEP organisations, which may imply a connection between the scale of the private sector and local government revenue and the effectiveness of the local FEDEP organisation.

\footnotetext{
${ }^{5}$ The lowest average scores achieved (as a percentage of the total possible) was for phase 3 at $60.4 \%$ compared to the highest of $76.1 \%$ for phase 1 . The greatest range of scores achieved (as a percentage of the total possible) and the largest standard deviations were apparent for phases 3 and 4 .
} 
Across the case study localities, our evidence summarised in table 3 suggests that the adaptive efficiency of the FEDEP institutions could be considered mixed in terms of their contributions to joint action at the level of clusters. The importance of social capital to the development of industry clusters and the need for its development in Indonesia has been emphasised (JICA, 2004). In Indonesia, industry clusters are often concentrated at the level of villages and are at least partly embedded in the strong social bonds and associated institutions of traditional Javanese culture. These include musyawarah (discussion or negotiation) and arisan (regular social gatherings and collective arrangements for saving money). These traditions could be a major source of social capital for industry clusters in Central Java (Interview 1). However, it is also possible they may be a source of inertia for the private sector. In several instances there seemed to have been protracted periods of negotiation to find suitable cluster leaders. In Laweyan, an outsider emerged as the batik industry cluster leader in order to generate a measure of trust among the different producer interests and in order to mobilise the local community to support the idea of batik production and tourism alongside residential uses (Interview 4). ${ }^{6}$

Across the six industry clusters in four local authority areas, our study provided one notable example of the significant build-up of institutions designed specifically to support joint action. The strength of the FEDEP in Pekalongan in comparison to others appears to stem from the input of the private sector as members of the FEDEP board and the responsiveness of the FEDEP to private sector initiatives. Several key institutions devoted to the batik industry have been initiated by the FEDEP in Pekalongan. These include the Setono grocery batik market (which has grown from having 55 traders in 2002 to 700 today), a batik museum, a batik education institution (Pusmanu Polytechnic), the branding of two batik kampongs (Kauman and Pesindon) and an International Batik Centre (Interview 6). While these developments appear likely to underpin the continued scale of the industry it is less clear what role they have played in deepening the organisation and collective efficiency of the industry.

Elsewhere the development of local institutions to underpin joint action is much more limited and often, with regards to the likes of training, conducted by leading businesses within the industry clusters. The head of the batik Kauman cluster in Surakarta, for example, trains people in his own business premises. The involvement of a vocational school in providing some training courses geared towards employment in businesses operating in the cluster has been at the initiative of the school itself and not the FEDEP or the industry cluster forum.

\section{Conclusion}

In this paper we have documented one important initiative concerned with promoting joint action in industry clusters in a developing country. The creation and virtually complete coverage of these new FEDEP institutions and arrangements for monitoring performance and exchanging practice across Central Java are achievements in themselves. The FEDEPs and their respective industry cluster forums might be regarded as interim institutions in the vast laboratory for policy fomentation and exchange that is Indonesia. As interim institutions they have been struggling to define their role in shaping joint action for the promotion of external economies in industry clusters. To date, and in comparison to other interim institutions (Wollenburg, 2013), they do not appear to have been captured by elite interests. These new local institutions vary in terms of their status, organisation and resources and it will be important to examine how they mature in the coming years.

However, at the outset of the paper we also drew attention to the likely limits of efforts to promote joint action. These limits included issues inherent to the organisation of any industry cluster and assumptions regarding whether external economies are indeed latent and can be

\footnotetext{
${ }^{6}$ Some measure of the time required for new policy implementation is provided by the 104 meetings that former Surakarta mayor Joko Widodo was said to have had in order to secure an acclaimed relocation of street vendors (Bunnell et al, 2013: 864).
} 
mobilised through joint action (Moreno-Monroy, 2012; Perry, 2005). First, external economies may simply not be latent in several of the industry clusters we examined which had lost critical mass. This suggests that the timing of interventions in support of joint action institutional capacity building is crucial. Second, although we were not able to delve deeply into whether businesses were unable to exploit external economies as a result of internal constraints on business growth, there was enough evidence from the conflicts that existed within industry clusters to suggest that the segmentation of industry remains a major issue for policy to address (Moreno-Monroy, 2012; Nichter and Goldmark, 2009). This tends to indicate that the concept of (horizontal and vertical) joint action among businesses may understate the extent to which 'Even where a collective capacity to compete, adapt and innovate has emerged, it is important not to expect an island of unity and solidarity' (Schmitz, 1995: 534).

The theory of industry clustering or agglomeration contains some troubling elements of circularity (Phelps, 1992), among which is the difficulty of demonstrating whether institutions have been cause or effect of collective business performance. First, then, inspection of our six industry cluster cases suggests that the new FEDEP institutions are likely to have been as yet a modest causal contributor both to efforts at joint action and to the performance of industry clusters. If anything, joint action and associated institutions appeared to have been stronger in the past - reflecting the thought that industry institutions have more likely been a consequence of the past development of industry clusters. Beyond this imponderable, limits to policy for joint action also presented themselves in terms of the difficulties of designing appropriate institutions with a measure of adaptive efficiency (North, 2000). Thus, second, despite GIZs long presence in the development field including in Indonesia, our paper revealed some glimpses of the gap that can exist between initial hopes and expectations regarding institutional support for new institutional capacity and the reality in developing countries. Some of this gap is generated as a result of the budgetary constraints on institutional and policy development found in a developing country like Indonesia (Masser, 1986). Third, however, beyond this, the gap between hopes and realities has as much to do with the commitment and abilities of the local government and political leaders involved and even perhaps some aspects of extant local social institutions. Thus, in several of the efforts to promote joint action we reported on, the situation might be characterised as one of joint inaction as observed a decade ago in a JICA (2004) study. Nevertheless, while there has been a degree of inaction on the part of some of these new local institutions to foster the development of industry clusters, this might be a harsh judgement to pass on an initiative that has been in existence for only a decade, when set against a recent period of turmoil and when seen in relation to the very long term over which similar institutions emerged historically in Europe.

The thrust of this paper has been to go beyond merely the recognition of, and advocacy for, the institutional basis of localised external economies. Theory and policy advocacy can usefully still be contextualised both to the specifics of individual developing countries (Altenburg and Meyer-Stamer, 1999) and to longer-term historical trends in the organisation of societies and international trade and investment. Here, a fruitful dialogue can continue to be had between economists and economic geographers (Scott, 1983, 1986; Storper, 1995), scholars in development studies (Schmitz, 2005; Weijland, 1999) and anthropologists and historians (Perlin, 1983).

\section{Acknowledgements}

The authors would like to thank the editor and two anonymous referees for their helpful comments on a previous draft of this paper. Nicholas Phelps is grateful for funding provided by the Bartlett School of Planning, University College London and the National Geographic Exploration Fund (GEFNE106-14). 


\section{References}

Altenburg, T. and Meyer-Stamer, J. (1999) 'How to promote clusters: policy experiences from Latin America', World Development 27: 1693-1713

Amin, A and Thrift, N. (1982) 'Neo-Marshallian nodes in global networks', International Journal of Urban and Regional Research 16: 571-587

Bunnell, T., Miller, M., Phelps, N.A. and Taylor, J. (2013) 'Urban development in a decentralised Indonesia: two success stories?', Pacific Affairs 86: 857-876

Gordon, I. and McCann, P. (2000) 'Industrial clusters: complexes, agglomeration and/or social networks', Urban Studies 37: 513-532

GTZ (2001) Minutes of Technical Meeting between GTZ and Bappenas Concerning Economic and Human Resources Development (EHRD) Program. GTZ, Jakarta.

GTZ (2004) FEDEP, Dialogue Forum Introducer of Economic Democratization Process in Central Java. GTZ, Jakarta.

GTZ (2008) Rattan Furniture Value Chain Promotion in the Solo Region, Central Java Indonesia. GTZ, Jakarta.

Hadiz, V. and Robison, R. (2005) 'Neo-liberal reforms and illiberal consolidations: the Indonesian paradox', Journal of Development Studies 41: 220-241

Humphrey, J., \& Schmitz, H. (2002) 'How does insertion in global value chains affect upgrading in industrial clusters', Regional Studies 36: 1017-1027.

JICA (2004) The Study on Strengthening Capacity of SME Clusters in Indonesia. Japan International Cooperation Agency, Tokyo

Kabupaten Jepara (2014) Jepara Dalam Angka, 2014. Badan Pusat Statistik Jepara, Kabupaten Jepara.

Kabupaten Jepara (2014) Product Domestik Regional Bruto, 2013. Badan Pusat Statistik Jepara, Kabupaten Jepara.

Kabupaten Sukoharjo (2014) Kabupaten Sukoharjo Dalam Angka, 2014. Badan Pusat Statistik Kabupaten Sukoharjo, Kabupaten Sukoharjo.

Kota Pekalongan (2013) Kota Pekalongan Dalan Angka, 2013. Badan Pusat Statistik Kota Pekalongan, Pekalongan.

Kota Surakarta (2013) Surakarta Dalam Angka, 2013. Badan Pusat Satitstik Kota Surakarta, Kota Surakarta.

McGee, T. (1991) 'The emergence of desakota regions in Asia: expanding a hypothesis', pp. 3-25 in Ginsborg, N., Koppel, B. and McGee, T. Eds. The Extended Metropolis: Settlement Transition in Asia. University of Hawaii Press, Honolulu.

Masser,I. (1986) 'The transferability of planning experiences between countries', pp. 165-175 in Masser, I. and Williams, R. Eds. Learning from Other Countries. GeoBooks, Norwich.

Moreno-Monroy, A (2012) 'Informality in space: understanding agglomeration economies during economic development', Urban Studies 49: 2019-2030.

Nadvi, K. (1999) 'Collective efficiency and collective failure: the response of the Sialkot surgical instrument cluster to global quality pressures', World Development 27: 1605-1626

Nadvi, K. (2007) 'The cutting edge: collective efficiency and international competitiveness in Pakistan', Oxford Development Studies 27: 81-107

Nichter, S.and Goldmark, L. (2009) 'Small firm growth in developing countries', World Development 37: 1453-1464

North, D.C. (1990) Institutions, institutional change and economic performance. CUP, Cambridge.

North, D.C. (2010) Understanding the process of economic change. Princeton University Press, Princeton NJ.

P5 Universitas Diponegoro (2013) Laporan Kegiatan Monitoring and Evaluasi: Pengembangan Ekonomi Lokal (PEL) Provinsi Jawa Tengah. P5 Universitas Diponegoro, Semarang.

P5 Universitas Diponegoro (2014) Pedoman Umum FEDEP. P5 Universitas Diponegoro, Semarang.

Perlin, F.(1983) 'Proto-industrialization and pre-colonial South Asia', Past and Present 98: 3095 
Perry. M. (2005) 'Business clusters in the south: A critical appraisal from Indonesian evidence', Singapore Journal of Tropical Geography 26: 227-243

Phelps, N. A. (1992) 'External economies, agglomeration and flexible accumulation', Transactions of the Institute of British Geographers 17: 35-46.

Phelps, N.A. Bunnell, T., Miller, M. and Taylor, J. (2014) 'Urban inter-referencing within and beyond Indonesia', Cities 39:

Pritchett, L., Woolcock, M. and Andrews, M. (2013) 'Looking like a state: techniques of persistent failure in state capability for implementation' Journal of Development Studies 49: 118

Provinsi Jawa Tengah (2013) Provincial Family Welfare (2013). Badan Pusat Statistik Provinsi Jawa Tengah, Semarang.

Rodrik, D. (2008) 'Second best institutions', American Economic Review 98: 100-104

Sandee, H., Isdijoso, B. and Sulandjari, S. (2002) SME Clusters in Indonesia: An Analysis of Growth Dynamics and Employment Conditions. ILO, Geneva.

Sandee, H., Rietveld, P., Supratikno, H. and Yuwono, P. (1994) 'Promoting small scale cottage industries in Indonesia: An impact analysis for Central Java', Bulletin of Indonesian Economic Studies 30: 115-142

Sandee, H. and Weijland, (1989) 'Rural cottage industry in transition: the roof tile industry in kabupaten Boyolali, Central Java', Bulletin of Indonesian Economic Studies 25: 79-98

Schmitz, H. (1982) 'Growth constraints on small-scale manufacturing in developing countries: a critical review', World Development 10: 429-450

Schmitz, H. (1995)'Collective efficiency: growth path for small scale industry', Journal of Development Studies 31: 529-66

Schmitz, H. (1999) 'Collective efficiency and increasing returns' Cambridge Journal of Economics 23: 465-483

Scitovsky, T. (1954) 'Two concepts of external economies', The journal of Political Economy: 143-151.

Scott, A.J. (1983) 'Industrial organization and the logic of intra-metropolitan location, 1: theoretical considerations', Economic Geography 59: 233-250

Scott, A.J. (1986) Industrial organization and location: division of labor, the firm and spatial process', Economic Geography 62: 215-231

Scott, A.J. (2002) 'Regional push: towards a geography of development and growth in low and middle income countries', Third World Quarterly 23: 137-161

Sekimoto, T. (2000) 'Innovation, change and tradition in the batik industry', pp.23-31 in Hitchcock, M. and Nuryanti, W. Eds. Building o Batik: the globalization of a craft community. Ashgate, Aldershot.

Storper, M. (1995) 'The resurgence of regional economies, ten years later: the region as a nexus of untraded interdependencies', European Urban and Regional Studies 2: 191-221

Taylor, M. and Thrift, N. (1982) 'Industrial linkage and the segmented economy 1: some theoretical proposals', Environment and Planning A 14: 1601-1613

Turner, S. (2003) Indonesia's Small Entrepreneurs: Trading on the Margins. RoutledgeCurzon, London.

Von Luebke, C. (2009) 'the political economy of local governance: findings from an Indonesian field study', Bulletin of Indonesian Economic Studies 45: 201-230

Von Luebke, C., McCulloch, N. And Pantunru, A.A. (2009) 'Heterdox reform symbioses: the political economy of investment climate reforms in Solo, Indonesia', Asian Economic Journal 23: $269-296$

Weijland, H. (1999) 'Microenterprise clusters in rural Indonesia: Industrial seedbed and policy target', World Development 27: 1515-1530

Wollenberg, E., Moeliono, M., Limberg, G., Iwan, R., Rhee, S. and Sudana, M. (2006) 'Between state and society: local governance of forestry in Malinan, Indonesia', Forest Policy and Economics 8: 421-433 
Figure 1 Map of regencies (kabupaten) and cities (kota) in Central Java

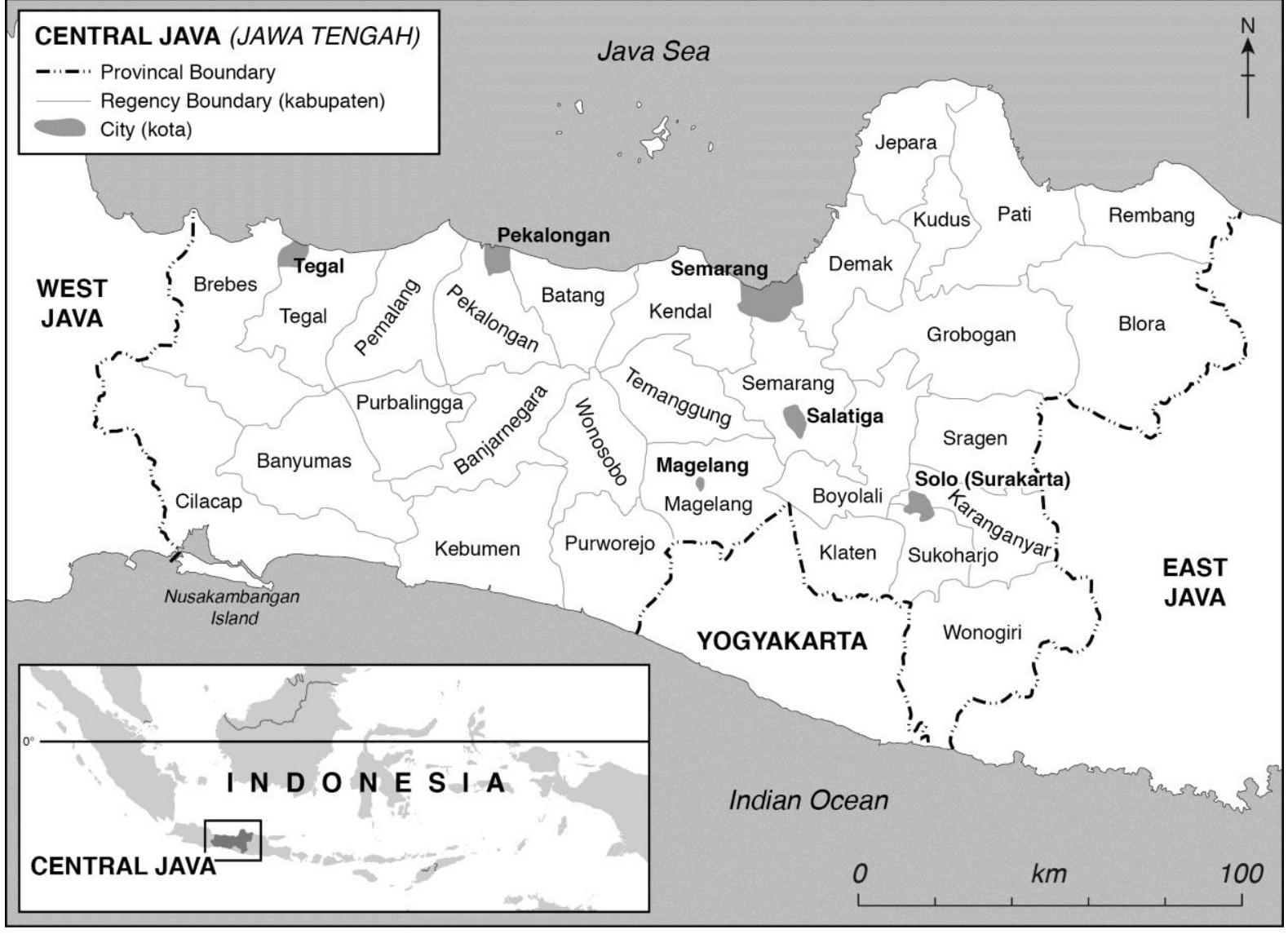


Figure 2 Evaluation scores for regency and city local economic forums

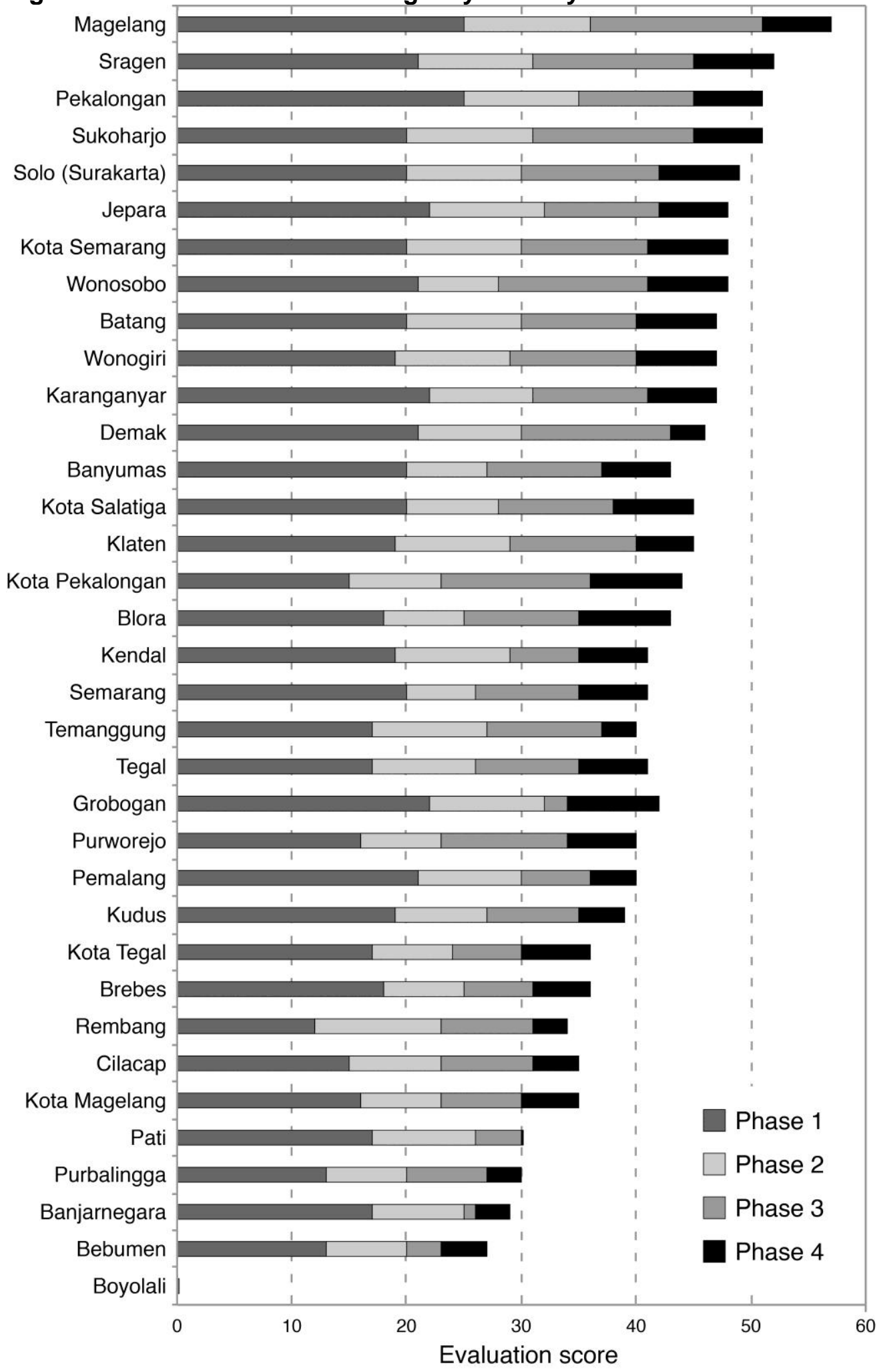


Table 1 Basic descriptors of study districts/cities

\begin{tabular}{|l|l|l|l|l|}
\hline District/city & Population & $\begin{array}{l}\text { GDP per capita } \\
\text { (Rupiah millions } \\
\text { current prices) }\end{array}$ & $\begin{array}{l}\text { Number of } \\
\text { welfare families } \\
\text { as per cent of } \\
\text { total population }\end{array}$ & $\begin{array}{l}\text { Land } \\
\text { (Hectares) }\end{array}$ \\
\hline Sukoharjo & $863,693(\mathrm{~b})$ & $14.34(\mathrm{a})$ & $20.12 \%(\mathrm{c})$ & 46,666 \\
\hline Jepara & $1,153,213(\mathrm{c})$ & $10.79(\mathrm{c})$ & $27.58 \%(\mathrm{c})$ & 100,413 \\
\hline Surakarta & $500,171(\mathrm{~b})$ & $24.34(\mathrm{~b})$ & $9.63 \%(\mathrm{c})$ & 4,404 \\
\hline Pekalongan & $290,870(\mathrm{c})$ & $16.13(\mathrm{~b})$ & $18.28(\mathrm{c})$ & 4,525 \\
\hline
\end{tabular}

(a) 2011

(b) 2012

(c) 2013

Sources: Kabupaten Jepara (2014a); Kabupaten Jepara (2014b); Kabupaten Sukoharjo (2014); Kota Surakarta (2013), Kota Pekalongan (2013), Provinsi Jawa Tengah (2013). For the sake of rough illustration, the highest value of 24.34 million rupiah per capita GDP in Surakarta amounts to US\$1718 at exchange rate as of 25 October 2015.

Table 2 Provincial and local government contributions to local FEDEPs in million rupiah

\begin{tabular}{|l|l|l|l|l|l|l|l|l|l|l|l|l|}
\hline $\begin{array}{l}\text { Distri } \\
\text { ct/ } \\
\text { city }\end{array}$ & 2009 & & 2010 & & 2011 & & 2012 & & 2013 & & $\begin{array}{l}\text { Sum } \\
2009 \\
- \\
2013\end{array}$ & \\
\hline & $\begin{array}{l}\text { Prov } \\
\text { ince }\end{array}$ & $\begin{array}{l}\text { Cit } \\
\text { y/ } \\
\text { dist } \\
\text { rict }\end{array}$ & $\begin{array}{l}\text { Prov } \\
\text { ince }\end{array}$ & $\begin{array}{l}\text { Cit } \\
\text { y/ } \\
\text { dist } \\
\text { rict }\end{array}$ & $\begin{array}{l}\text { Prov } \\
\text { ince/ }\end{array}$ & $\begin{array}{l}\text { Cit } \\
\text { y/ } \\
\text { dist } \\
\text { rict }\end{array}$ & $\begin{array}{l}\text { Prov } \\
\text { ince }\end{array}$ & $\begin{array}{l}\text { Cit } \\
\text { y/ } \\
\text { dist } \\
\text { rict }\end{array}$ & $\begin{array}{l}\text { Prov } \\
\text { ince }\end{array}$ & $\begin{array}{l}\text { Cit } \\
\text { y/ } \\
\text { dist } \\
\text { rict }\end{array}$ & $\begin{array}{l}\text { Prov } \\
\text { ince }\end{array}$ & $\begin{array}{l}\text { Cit } \\
\text { y/ } \\
\text { dist } \\
\text { rict }\end{array}$ \\
\hline $\begin{array}{l}\text { Sukoh } \\
\text { arjo }\end{array}$ & 75 & 30 & 75 & 35 & 80 & 30 & 90 & 35 & 90 & 60 & 410 & 190 \\
\hline $\begin{array}{l}\text { Jepar } \\
\text { a }\end{array}$ & 90 & 65 & 85 & 65 & 85 & 0 & 100 & 20 & 100 & 20 & 460 & 170 \\
\hline $\begin{array}{l}\text { Surak } \\
\text { arta }\end{array}$ & 80 & 25 & 70 & $\begin{array}{l}17 . \\
5\end{array}$ & 60 & $\begin{array}{l}17 . \\
5\end{array}$ & 75 & 40 & 80 & 15 & 365 & 210 \\
\hline $\begin{array}{l}\text { Pekal } \\
\text { ongan }\end{array}$ & 75 & 75 & 75 & 75 & 75 & 75 & 80 & 25 & 80 & 20 & 385 & 270 \\
\hline
\end{tabular}

Source: Forum Pengembangan Ekonomidan Sumberdaya (FPESD) Bappeda, Jawa Tengah, Semarang. For the sake of rough illustration, the highest value of 460 million rupiah worth of funding to Jepara FEDEP over the 4 years amounts to US\$33,776 at exchange rate as of 25 October 2015. 
Table 3 Summary findings of study clusters and district and city FEDEP organisations.

\begin{tabular}{|c|c|c|c|c|c|c|}
\hline & \multicolumn{2}{|l|}{ Surakarta } & \multirow{2}{*}{\multicolumn{2}{|c|}{ Sukoharjo }} & \multirow[t]{2}{*}{ Jepara } & \multirow[t]{2}{*}{ Pekalongan } \\
\hline & \multicolumn{2}{|c|}{ Kauman Lawevan } & & & & \\
\hline $\begin{array}{l}\text { Industry } \\
\text { cluster }\end{array}$ & Batik & batik & $\begin{array}{l}\text { Wooden } \\
\text { furniture }\end{array}$ & \begin{tabular}{|l} 
Rattan \\
furniture
\end{tabular} & Wood carving & batik \\
\hline $\begin{array}{l}\text { Latency of } \\
\text { external } \\
\text { economies }\end{array}$ & & & & & & \\
\hline $\begin{array}{l}\text { Critical } \\
\text { Mass }\end{array}$ & $\begin{array}{l}\text { No: much } \\
\text { and rel } \\
\text { neighbou } \\
\text { districts }\end{array}$ & $\begin{array}{l}\text { diminished } \\
\text { ocated to } \\
\text { ing }\end{array}$ & $\begin{array}{l}\text { Yes: but } \\
\text { much } \\
\text { diminished }\end{array}$ & $\begin{array}{l}\text { Yes; but } \\
\text { diminished }\end{array}$ & $\begin{array}{l}\text { Yes: } \\
\text { emerging but } \\
\text { with limits to } \\
\text { growth }\end{array}$ & $\begin{array}{l}\text { Yes: still quite } \\
\text { sizeable }\end{array}$ \\
\hline $\begin{array}{l}\text { Industry-self } \\
\text { organisation }\end{array}$ & Vertical & Horizontal & Horizontal & Vertical & $\begin{array}{l}\text { Partial } \\
\text { horizontal }\end{array}$ & Vertical \\
\hline $\begin{array}{l}\text { Institutions } \\
\text { for joint } \\
\text { action }\end{array}$ & & & & & & \\
\hline $\begin{array}{l}\text { Appropriate } \\
\text { design: } \\
\text { purpose } \\
\text { and } \\
\text { strategic } \\
\text { focus }\end{array}$ & $\begin{array}{l}\text { Yes: foc } \\
\text { cluster at }\end{array}$ & $\begin{array}{l}\text { is on one } \\
\text { a time }\end{array}$ & $\begin{array}{l}\text { No: Wide } f \\
\text { clusters }\end{array}$ & ocus on ten & $\begin{array}{l}\text { No: continued } \\
\text { debate and } \\
\text { large number } \\
\text { of clusters } \\
\text { supported }\end{array}$ & $\begin{array}{l}\text { Yes: limited } \\
\text { focus on two } \\
\text { clusters }\end{array}$ \\
\hline $\begin{array}{l}\text { Adaptive } \\
\text { efficiency: } \\
\text { financial } \\
\text { and human } \\
\text { resources }\end{array}$ & $\begin{array}{l}\text { Yes: fin } \\
\text { human } \\
\text { significan } \\
\text { augmente } \\
\text { local anc } \\
\text { governme }\end{array}$ & $\begin{array}{l}\text { ance and } \\
\text { resources } \\
\text { ly by non- } \\
\text { provincial } \\
\text { nt actors }\end{array}$ & $\begin{array}{l}\text { No: one pers } \\
\text { multiple roles }\end{array}$ & on performing & $\begin{array}{l}\text { Yes: early } \\
\text { and continued } \\
\text { financial and } \\
\text { organisational } \\
\text { resources } \\
\text { committed }\end{array}$ & $\begin{array}{l}\text { Yes: } \\
\text { organisational } \\
\text { resources } \\
\text { committed } \\
\text { with private } \\
\text { sector } \\
\text { involvement } \\
\text { and clear } \\
\text { organisational } \\
\text { structure and } \\
\text { rotation }\end{array}$ \\
\hline $\begin{array}{l}\text { Adaptive } \\
\text { efficiency: } \\
\text { social } \\
\text { context }\end{array}$ & $\begin{array}{l}\text { Unclear: } \\
\text { how tra } \\
\text { arisan } \\
\text { musyawa } \\
\text { contribute } \\
\text { adaptatio } \\
\text { industry }\end{array}$ & \begin{tabular}{rr} 
& \multicolumn{2}{c}{ unclear } \\
ditions of \\
& and \\
rah will & to \\
& of \\
&
\end{tabular} & $\begin{array}{l}\text { Unclear: } \\
\text { can } \\
\text { horizontal } \\
\text { coordination } \\
\text { be extended } \\
\text { under } \\
\text { current } \\
\text { syndicate } \\
\text { model? }\end{array}$ & $\begin{array}{l}\text { No: } \\
\text { coordination } \\
\text { unlikely to } \\
\text { deepen in } \\
\text { presence of } \\
\text { significant } \\
\text { intra- } \\
\text { industry } \\
\text { dispute? }\end{array}$ & $\begin{array}{l}\text { Unclear: } \\
\text { horizontal } \\
\text { industry } \\
\text { organisation } \\
\text { may deepen }\end{array}$ & $\begin{array}{l}\text { Yes: some } \\
\text { evidence of } \\
\text { new } \\
\text { institutions }\end{array}$ \\
\hline
\end{tabular}

